\title{
PREDIKSI KEBUTUHAN LISTRIK TIGA FASE DENGAN JARINGAN SYARAF TIRUAN BERDASARKAN DATA ERTE SYSTEM UNIVERSITAS LAMPUNG
}

\author{
Dikpride Despa $^{1)}$, F.X. Arinto $^{2)}$, Jofanda Delano ${ }^{3)}$, dan Meizano Ardhi Muhammad ${ }^{4)}$ \\ 1,2,3,4 Jurusan Teknik Elektro, Fakultas Teknik, Universitas Lampung \\ 1,2,3,4 Jl. Soemantri Brojonegoro no. 1 Rajabasa, Bandar Lampung, 35135 \\ E-mail : despa@eng.Unila.ac.id ${ }^{1)}$, fx.arinto@eng.Unila.ac.id ${ }^{2)}$, jofandadelano25@gmail.com ${ }^{3)}$, meizano@eng.Unila.ac.id ${ }^{4)}$
}

\begin{abstract}
ABSTRAK
Electricity Real-Time Estimation (ERTE) System Universitas Lampung, melalui pemanfaatan IoT (Internet of Things), memberikan informasi mengenai pemakaian listrik tiga fase dalam waktu nyata dan menympannya secara historis. Data tersebut dapat digunakan untuk melakukan prediksi kebutuhan listrik masa depan. Jaringan Syaraf Tiruan merupakan metode yang memungkinkan melakukan prediksi berdasarkan pengamatan pada pola data yang ada seperti layaknya otak manusia. Penelitian dilakukan dalam empat bagian, pertama adalah penentuan lapisan masukan (input layer) terdiri dari tanggal, hari, hari libur, jam, ruangan, dan pemakaian listrik serta lapisan keluaran (output layer) terdiri dari prediksi kebutuhan listrik; kedua adalah pelatihan model; ketiga adalah pengujian Jaringan Syaraf Tiruan. Semua bagian tersebut dibagi ke masing-masing fase RST. Pada bagian keempat, dilakukan prediksi kebutuhan listrik berdasarkan hasil estimasi dari setiap fase. Setelah dilakukan pelatihan dan pengujian dari model jaringan syaraf tiruan, prediksi kebutuhan listrik tiga fase menggunakan Jaringan Syaraf Tiruan memiliki tingkat akurasi yang tinggi, yaitu $99,11 \%$. Hal ini menunjukkan bahwa Jaringan Syaraf Tiruan dengan Backpropagation dapat digunakan untuk melakukan prediksi kebutuhan daya listrik dengan cukup akurat. Backpropagation menurunkan tingkat error yang cukup rendah sehingga hasil prediksi dapat dijadikan dasar dalam melakukan pengelolaan dan perencanaan perkiraan kebutuhan daya listrik untuk gedung yang menggunakan listrik tiga fase.
\end{abstract}

Kata Kunci: Internet of Things, Jaringan Syaraf Tiruan, Listrik Tiga Fase, backpropagation, prediksi

\section{PENDAHULUAN}

Pemakaian listrik tiga fase pada gedung dilakukan karena kebutuhan listriknya yang besar. Dengan menggunakan tiga fase, listrik yang tersedia lebih konstan yang mendukung penggunaan perangkat listrik dalam jumlah besar dan daya tinggi dengan lebih baik. Karena listrik tiga fase terdiri dari tiga fase yang berbeda, harus dilakukan pengukuran untuk setiap fase yang digunakan. Hal ini berbeda dengan listrik satu fase yang hanya memiliki satu fase untuk diukur. Di Indonesia, umumnya pengukuran listrik tiga fase masih menggunakan cara sederhana, yaitu melihat pemakaian pada meteran listrik. Dampaknya adalah penggunaan listrik tidak terawasi dengan baik dan cenderung hanya diketahui melalui pembayaran tagihan listrik setiap bulannya.

Pengukuran kebutuhan daya listrik merupakan kebutuhan di dunia industri. Pengukuran waktu-nyata yang terintegrasi mendukung peningkatan efisiensi energi listrik (Shrouf \& Miragliotta, 2015). Penelitian telah dilakukan untuk mengukur efisiensi energi untuk mendeteksi pola konsumsi energi abnormal dan mengkuantifikasi kesenjangan efisiensi energi (Tan, et al., 2017). Pengukuran pemakaian energi listrik bahkan menunjukkan bahwa green building yang dirancang khusus untuk efisiensi energi masih belum efisien, pengawasan pemakaian listrik menjadi integral dalam menjamin bahwa energi listrik digunakan secara proporsional (Pan, et al., 2015). Pada skala yang lebih besar seperti Smart City, energi listrik harus dapat dikelola dengan efisien mengingat kebutuhan listrik yang memadai untuk suplai ke rumah dan industri (Ramakrishnan \& Gaur, 2016). Kegagalan dalam menjamin ketersediaan listrik dapat berakibat kegagalan sistem. Internet of Things (IoT) memungkinkan kondisi di dunia nyata untuk terhubung melalui sensor dan aktuator yang dapat menyediakan kumpulan data yang besar agar bisa dianalisis, diinterpretasi, dan diutilisasi (Asghar, et al., 2015), khususnya dalam hal ini adalah pemakaian listrik.

Oleh karena itu, untuk memudahkan pemantauan pemakaian listrik, dikembangkan ERTE System yang terdiri dari IoT dan Sistem Informasi Dashboard (Despa, et al., 2019). ERTE System merupakan pengembangan dari Real-Time Energy Monitoring System (REMS) yang mengukur penggunaan energi listrik terakhir berdasarkan KWh (Despa, et al., 2018). Peningkatan pada ERTE System adalah pengawasan terhadap tegangan, arus, daya, faktor data, KWh, dan frekuensi terhadap tiga fasa yang direpresentasikan dalam grafik real-time berbasis waktu. Data pemakaian listrik disimpan secara historis pada basis data dan disajikan dalam bentuk visual. Besaran listrik di Gedung Jurusan Teknik Elektro, Fakultas Teknik, Universitas Lampung telah dipantau dan diukur oleh ERTE System Universitas Lampung (Delano, 2018). Hasil pengukuran tersebut dapat 
digunakan sebagai aspek perencanaan operasi tenaga listrik yang baik dan optimum, yaitu prediksi atau estimasi. Salah satu metode untuk memprediksi ketidaklinieran adalah menggunakan Jaringan Syaraf Tiruan (Jaringan Saraf Tiruan). Jaringan Syaraf Tiruan mengolah data mengikuti cara berpikir manusia dengan melihat pola yang ada pada kumpulan data. Variabel yang digunakan dalam metode Jaringan Syaraf Tiruan ini adalah data sistem kelistrikan (daya listrik setiap fase), data tanggal, data hari, data hari libur, dan data ruangan di masa lampau dimana data ini merupakan faktor yang mempengaruhi besar daya listrik pada gedung tersebut (Despa, et al., 2018).

Tujuan dari penelitian ini adalah untuk membuktikan bahwa metode Jaringan Syaraf Tiruan backpropagation dapat digunakan untuk prediksi dari data besaran listrik (daya listrik setiap fase) yang diukur oleh ERTE System di Gedung di Gedung Jurusan Teknik Elektro, Fakultas Teknik, Universitas Lampung.

\section{RUANG LINGKUP}

Dalam penelitian ini permasalahan mencakup:

1. Prediksi Kebutuhan Listrik Tiga Fase dengan Jaringan Syaraf Tiruan.

2. Data yang digunakan dalam melakukan prediksi adalah tanggal, hari, hari libur, jam, ruangan, dan pemakaian listrik yang didapatkan dari ERTE System Universitas Lampung.

3. Diharapkan didapatkan hasil prediksi yang cukup akurat dengan nilai di atas $85 \%$.

\section{BAHAN DAN METODE}

Dalam melakukan prediksi kebutuhan listrik menggunakan jaringan syaraf tiruan, data merupakan komponen utama. Data memiliki pola tertentu yang dapat membantu analisis dalam mendapatkan informasi yang diperlukan. Jaringan Syaraf Tiruan membantu manusia dengan menggali informasi yang ada pada kumpulan data dengan algoritma yang mengikuti cara berpikir manusia. Backpropagation adalah salah satu teknik untuk meningkatkan akurasi dari Jaringan Syaraf Tiruan.

\subsection{Jaringan Syaraf Tiruan}

Jaringan Syaraf Tiruan adalah sistem komputasi dengan arsitektur dan operasi diilhami dari pengetahuan tentang sel syaraf biologi di dalam otak. Hal tersebut menjadikan Jaringan Syaraf Tiruan sangat cocok untuk menyelesaikan masalah yang memerlukan logika yang sama seperti otak manusia (Yanto, et al., 2018).

Sistem jaringan syaraf tiruan ditentukan dalam 3 hal berikut (Atika Sari, 2006):

1. Pola-pola hubungan antar neuron yang disebut arsitektur jaringan

2. Metode penentuan bobot penghubung yang disebut training/learning/algoritma

3. Fungsi aktivasi yang digunakan.

Jaringan Syaraf Tiruan memproses masukan yang diberikan berdasarkan fungsi aktivasi yang kemudian diproses menjadi keluaran. Relasi antara masukan, fungsi aktivasi, dan keluaran dapat dilihat pada Gambar 1 .

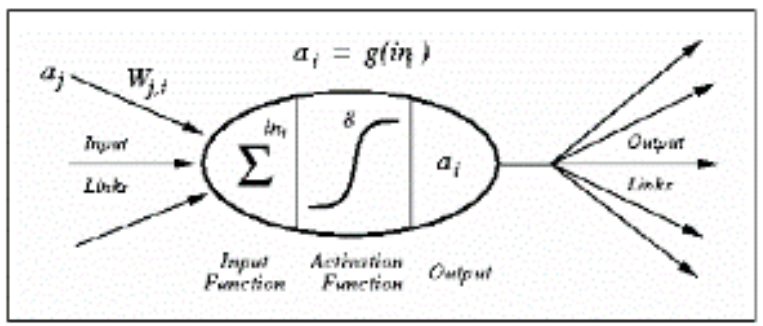

Gambar 1. Jaringan Syaraf Tiruan

Secara umum, lapisan pada Jaringan Syaraf Tiruan dibagi menjadi tiga bagian:

1. Lapis masukan (input layer) terdiri dari neuron yang menerima data masukan dari variabel X. Semua neuron pada lapis ini dapat terhubung ke neuron pada lapisan tersembunyi atau langsung ke lapisan luaran jika jaringan tidak menggunakan lapisan tersembunyi.

2. Lapisan tersembunyi (hidden layer) terdiri dari neuron yang menerima data dari lapisan masukan.

3. Lapisan luaran (output layer) terdiri dari neuron yang menerima data dari lapisan tersembunyi atau langsung dari lapisan masukan yang nilai luarannya melambangkan hasil kalkulasi dari $\mathrm{X}$ menjadi nilai. (Kusumadewi, 2004)

\subsection{Backpropagation}

Backpropagation adalah algoritma pembelajaran yang terawasi. Backpropagation biasanya digunakan dengan banyak lapisan untuk mengubah bobot-bobot yang terhubung dengan neuron-neuron yang ada pada lapisan tersembunyi. Algoritma backpropagation ini menggunakan error output untuk mengubah nilai bobotbobotnya. Untuk mendapatkan error, tahap forward propogation harus dikerjakan terlebih dahulu. Pada saat, forward propagation, neuron-neuron diaktifkan dengan menggunakan fungsi aktivasi yang dapat didiferensiasikan (Jek Siang, 2005). Arsitektur Backpropagation terdiri input layer, hidden layer, dan output layer. Hubungan arsitektur antara layer pada backpropagation dapat dilihat pada Gambar 2.

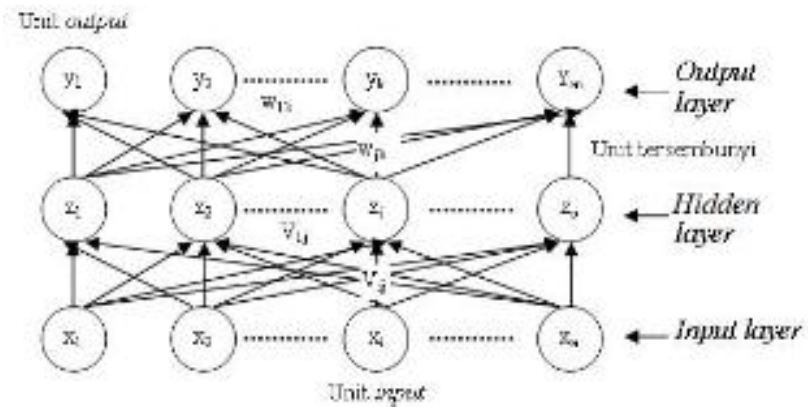

Gambar 2. Arsitektur Backpropagation

\subsection{Metode Penelitian}

Penelitian dilakukan dalam empat bagian, pertama adalah penentuan lapisan masukan (input layer) serta lapisan keluaran (output layer); kedua adalah pelatihan model Jaringan Syaraf Tiruan; ketiga adalah pengujian model Jaringan Syaraf Tiruan; dan keempat Prediksi 
Kebutuhan Daya Listrik. Keterkaitan setiap bagian dalam penelitian dapat dlihat pada Gambar 3.

\begin{tabular}{|c|c|c|}
\hline \multicolumn{3}{|c|}{ Penentuan Lapisan } \\
\hline Input Layer & & Layer \\
\hline \multicolumn{3}{|c|}{ Pelatihan Model Jaringan Syaraf Tiruan } \\
\hline Fase $\mathrm{R}$ & Fase $\mathrm{S}$ & Fase $\mathrm{T}$ \\
\hline \multicolumn{3}{|c|}{ Pengujian Model Jaringan Syaraf Tiruan } \\
\hline Fase $\mathrm{R}$ & Fase $\mathrm{S}$ & Fase T \\
\hline \multicolumn{3}{|c|}{ Prediksi Kebutuhan Daya Listrik } \\
\hline
\end{tabular}

Gambar 3. Bagan Alir Penelitian

\section{PEMBAHASAN}

Berdasarkan metode penelitian, empat bagian dilakukan secara bertahap karena tahapan selanjutnya hanya bisa dikerjakan setelah proses pada tahapan sebelumnya selesai.

\subsection{Penentuan Lapisan}

1. Input Layer

Input Layer yang digunakan untuk estimasi kebutuhan konsumsi daya listrik pada Gedung Jurusan Teknik Elektro Fakultas Teknik Unila didasarkan pada data tanggal, hari, hari libur, jam, ruangan, dan pemakaian listrik. Rincian data yang digunakan dapat dilihat pada Tabel 1.

\section{Tabel 1. Input Layer}

\begin{tabular}{|l|l|}
\hline No. & Pola Input Jaringan Jaringan Syaraf Tiruan \\
\hline 1. & $\begin{array}{l}\text { Data tanggal dari bulan November 2017 sampai } \\
\text { dengan Mei 2018. }\end{array}$ \\
\hline 2. & $\begin{array}{l}\text { Data hari dari bulan November 2017 sampai dengan } \\
\text { Mei 2018. }\end{array}$ \\
\hline 3. & $\begin{array}{l}\text { Data hari libur dari bulan November 2017 sampai } \\
\text { dengan Mei 2018. }\end{array}$ \\
\hline 4. & $\begin{array}{l}\text { Data jam tiap harinya dalam range waktu 10 menit } \\
\text { tiap jam nya dari jam 08:00-17:00 di bulan November } \\
\text { 2017 sampai dengan Mei 2018. }\end{array}$ \\
\hline 5. & $\begin{array}{l}\text { Data ruangan yang digunakan di Gedung Jurusan } \\
\text { Teknik Elektro Fakultas Teknik Unila dari bulan } \\
\text { November 2017 sampai dengan Mei 2018. Data ini } \\
\text { didapatkan dari jadwal kuliah semester ganjil dan } \\
\text { semester genap tahun ajaran 2017/2018 yang ada di } \\
\text { jurusan Teknik Teknik Elektro Unila. }\end{array}$ \\
\hline 6. & $\begin{array}{l}\text { Data arus listrik dari bulan November 2017 sampai } \\
\text { dengan Mei 2018. }\end{array}$ \\
\hline
\end{tabular}

2. Output Layer

Keluaran yang diharapkan dari model atau jaringan adalah berupa estimasi konsumsi daya listrik pada waktu tersebut sesuai pola masukannya, sehingga jumlah neuron keluaran jaringan hanya 1 neuron. Hubungan data yang diproses oleh Model Jaringan Syaraf Tiruan dengan keluarannya dapat dilihat pada Gambar 4. Model Jaringan Syaraf Tiruan.

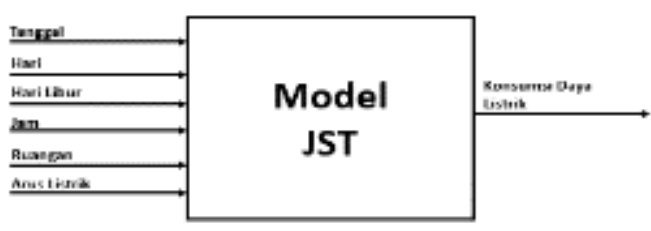

Gambar 4. Model Jaringan Syaraf Tiruan

\subsection{Pelatihan Model Jaringan Syaraf Tiruan}

Pada jaringan syaraf tiruan metode backpropogation, kinerja jaringan dapat dilihat pada error yang dihasilkan antara target yang ditentukan dan keluaran yang dihasilkan oleh Jaringan Syaraf Tiruan. Semakin kecil error yang dihasilkan maka model Jaringan Syaraf Tiruan tersebut semakin baik untuk digunakan pada proses prediksi. Pelatihan pada backpropogation ini menggunakan metode pencarian titik minimum untuk mencari bobot dengan error minimum.

Tingkat error pada pelatihan daya listrik sebelum dilakukan pengaturan pada dataset menunjukkan tingkat error yang cukup tinggi. Hal ini disebabkan oleh adanya dataset yang memiliki rentang atau selisih yang cukup jauh dengan rata-rata dataset atau dikenal dengan istilah outlier (nilai yang jauh atau berbeda sama sekali dengan nilai lain dalam kelompoknya) yaitu antara hari kerja (hari senin-jum'at) dan hari libur (hari sabtu-minggu). Sehingga, untuk meminimalisir data outlier pada dataset, data antara hari kerja dan hari libur dipisahkan. Parameter decay pula memberikan pengaruh terhadap tingkat akurasi karena decay akan mengurangi tingkat pembelajaran (learning rate) sehingga sistem dapat belajar lebih banyak belajar di awal pelatihan.

Setiap fase dilatih menggunakan dataset dan tingkat layer yang berbeda. Hal ini dikarenakan setiap fase memiliki tingkat penggunaan yang berbeda di lapangan.

Tabel 2. Pelatihan Model Jaringan Syaraf Tiruan Fase $\mathrm{R}$ menunjukkan penggunaan layer 63,73. Nilai Relative Absolute Error adalah 9,469\% sebelum pemisahan hari dan setelah pemisahan, hari kerja menjadi $0,884 \%$ dan hari libur $1,294 \%$.

Tabel 2. Pelatihan Model Jaringan Syaraf Tiruan Fase R

\begin{tabular}{|l|l|l|l|}
\hline \multicolumn{1}{|c|}{ Waktu } & Layer & Epoch & $\begin{array}{c}\text { Relative Absolute } \\
\text { Error }\end{array}$ \\
\hline Sebelum Dilakukan Pengaturan \\
\hline $02: 55: 07$ & 63,73 & 1000 & $9,469 \%$ \\
\hline Setelah Dilakukan Pengaturan \\
\hline Hari Kerja \\
\hline 00:57:54 & 63,73 & 1000 & $0,884 \%$ \\
\hline
\end{tabular}




\begin{tabular}{|l|l|l|l|}
\hline \multicolumn{4}{|l|}{ Hari Libur } \\
\hline $00: 39: 20$ & 63,73 & 1000 & $1,294 \%$ \\
\hline
\end{tabular}

Tabel 3. Pelatihan Model Jaringan Syaraf Tiruan Fase $\mathrm{S}$ menunjukkan penggunaan layer 33,43,30. Nilai Relative Absolute Error adalah $31,319 \%$ sebelum pemisahan hari dan setelah pemisahan, hari kerja menjadi $1,715 \%$ dan hari libur $1,546 \%$.

Tabel 3. Pelatihan Model Jaringan Syaraf Tiruan Fase $\mathbf{S}$

\begin{tabular}{|l|l|l|l|}
\hline \multicolumn{1}{|c|}{ Waktu } & Layer & Epoch & $\begin{array}{c}\text { Relative Absolute } \\
\text { Error }\end{array}$ \\
\hline Sebelum Dilakukan Pengaturan \\
\hline 01:00:08 & $33,43,30$ & 1000 & $31,319 \%$ \\
\hline Setelah Dilakukan Pengaturan \\
\hline Hari Kerja \\
\hline 00:37:42 & $33,43,30$ & 1000 & $1,715 \%$ \\
\hline Hari Libur \\
\hline 01:39:13 & $33,43,30$ & 1000 & $1,546 \%$ \\
\hline
\end{tabular}

Tabel 4. Pelatihan Model Jaringan Syaraf Tiruan Fase $\mathrm{T}$ menunjukkan penggunaan layer 63,73. Nilai Relative Absolute Error adalah 24,829\% sebelum pemisahan hari dan setelah pemisahan, hari kerja menjadi $1,726 \%$ dan hari libur $1,279 \%$.

Tabel 4. Pelatihan Model Jaringan Syaraf Tiruan Fase T

\begin{tabular}{|l|l|l|l|}
\hline \multicolumn{1}{|c|}{ Waktu } & Layer & Epoch & $\begin{array}{c}\text { Relative Absolute } \\
\text { Error }\end{array}$ \\
\hline Sebelum Dilakukan Pengaturan \\
\hline 03:51:03 & 63,73 & 1000 & $24,829 \%$ \\
\hline Setelah Dilakukan Pengaturan \\
\hline Hari Kerja \\
\hline 01:20:24 & 63,73 & 1000 & $1,726 \%$ \\
\hline Hari Libur \\
\hline 00:37:28 & 63,73 & 1000 & $1,279 \%$ \\
\hline
\end{tabular}

Diketahui bahwa galat akurasi model Jaringan Syaraf Tiruan yang dibangun berada di $\pm 1 \%$. Gambar 5 merupakan sebaran hasil model Jaringan Syaraf Tiruan setiap fase untuk hari kerja.

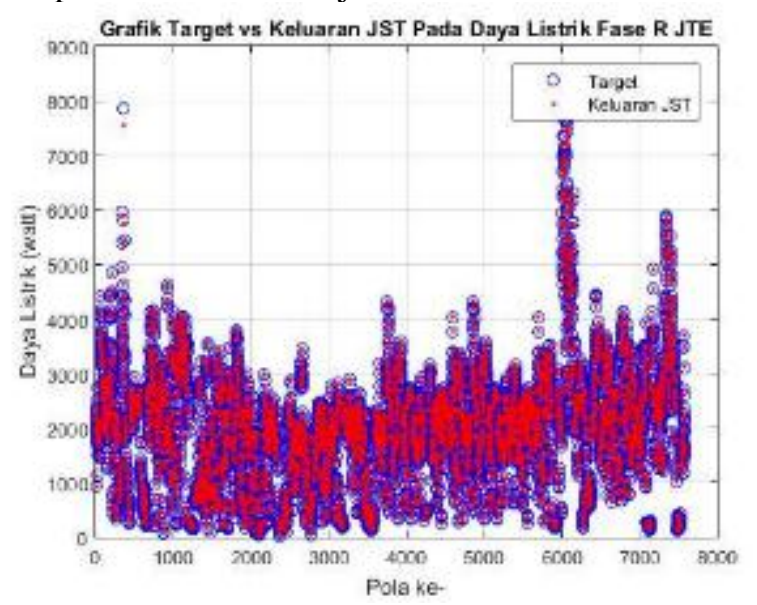

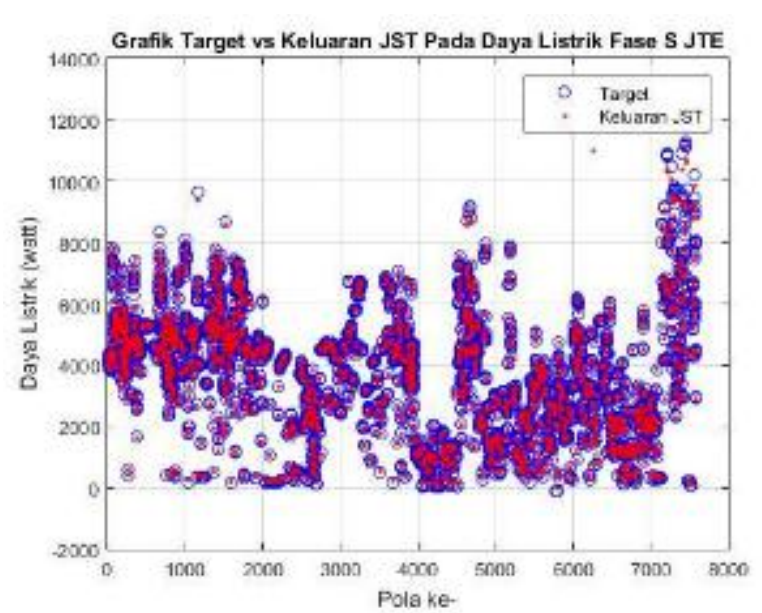

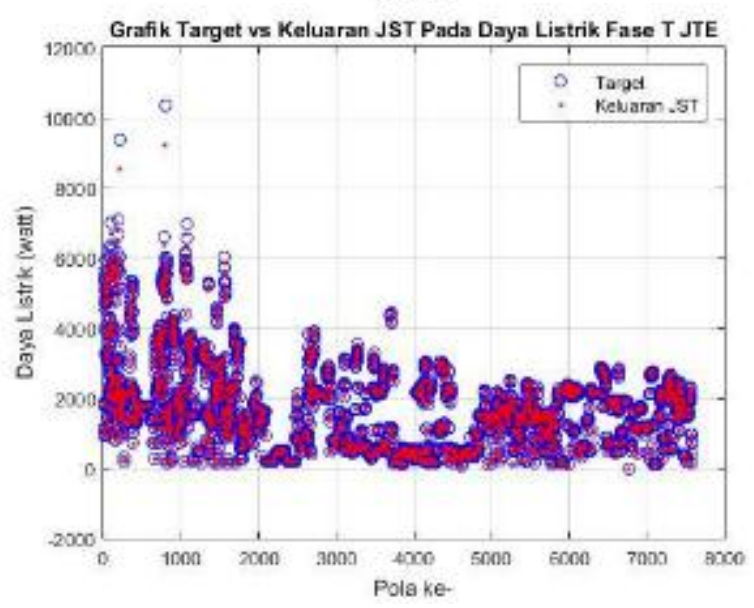

Gambar 5. Sebaran Hasil Pelatihan pada Hari Kerja (Senin-Jum'at)

Gambar 6 merupakan sebaran hasil model Jaringan Syaraf Tiruan untuk setiap fase pada hari libur. Dapat dilihat perbedaannya bahwa pemakaian daya listrik lebih rendah pada hari libur.

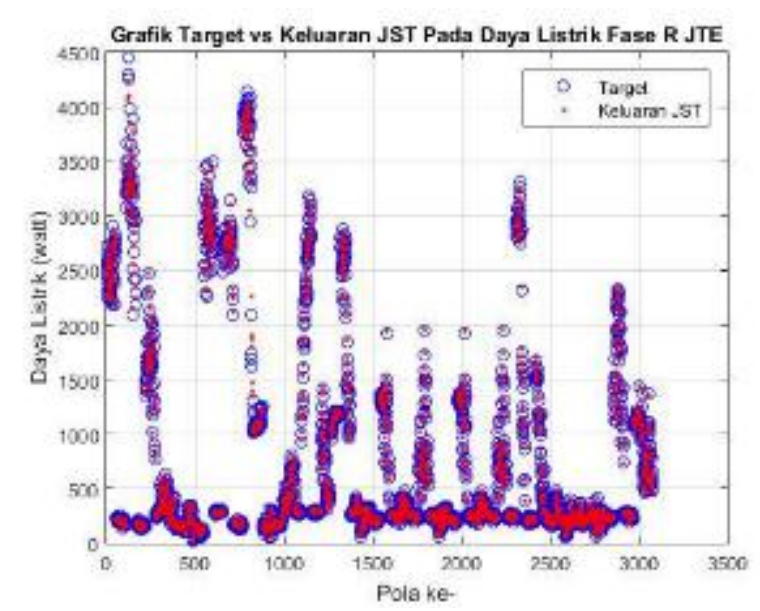



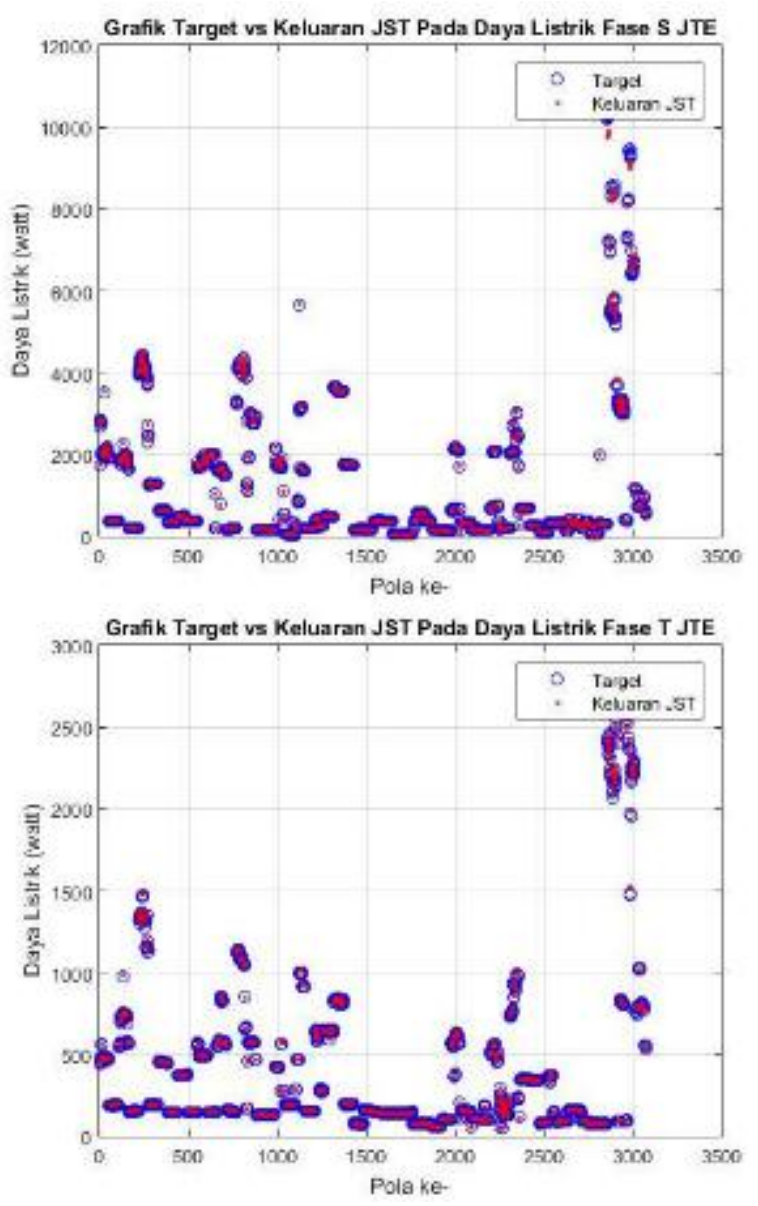

Gambar 6. Sebaran Hasil Pelatihan pada Hari Libur (Sabtu-Minggu dan Liburan)

Pelatihan ini dimaksudkan untuk mendapatkan informasi dari taburan data di masa lampau.

\subsection{Pengujian Model Jaringan Syaraf Tiruan}

Pengujian Model Jaringan Syaraf Tiruan adalah untuk mengevaluasi arsitektur Jaringan Syaraf Tiruan hasil pelatihan tersebut sudah baik atau belum untuk proses estimasi bulan kedepannya. Data yang digunakan adalah data pada bulan Mei 2018 dan dipisah untuk setiap fase.

Data sampel untuk pengujian model jaringan syaraf tiruan pada fase $\mathbf{R}$ dapat dilihat pada Tabel 5. Data sampel untuk pengujian model jaringan syaraf tiruan pada fase $S$ dapat dilihat pada

Tabel 6. Data sampel untuk pengujian model jaringan syaraf tiruan pada fase $\mathrm{T}$ dapat dilihat pada Tabel 7.

Tabel 5. Data Sampel Pengujian Model Jaringan Syaraf Tiruan Fase $\mathbf{R}$

\begin{tabular}{|l|l|l|l|l|}
\hline Tanggal & Jam & $\begin{array}{l}\text { Aktual } \\
\text { (Watt) }\end{array}$ & $\begin{array}{l}\text { Prediksi } \\
\text { (Watt) }\end{array}$ & Error (\%) \\
\hline 14-Mei-18 & $8: 00$ & 2621,838 & 2617,903 & 0,150086 \\
\hline 14-Mei-18 & $8: 10$ & 2660,449 & 2656,944 & 0,131745 \\
\hline 14-Mei-18 & $8: 20$ & 2888,117 & 2888,269 & 0,005263 \\
\hline 14-Mei-18 & $8: 30$ & 2727,185 & 2723,121 & 0,149018 \\
\hline
\end{tabular}

\begin{tabular}{|l|l|l|l|l|}
\hline $14-M e i-18$ & $8: 40$ & 2858,223 & 2854,29 & 0,137603 \\
\hline$\cdot$ & $\cdot$ & $\cdot$ & $\cdot$ & $\cdot$ \\
\hline $31-M e i-18$ & $16: 30$ & 272,733 & 280,27 & 2,763509 \\
\hline $31-M e i-18$ & $16: 40$ & 98,543 & 115,042 & 16,74294 \\
\hline $31-M e i-18$ & $16: 50$ & 97,621 & 110,202 & 12,8876 \\
\hline $31-M e i-18$ & $17: 00$ & 85,326 & 103,693 & 21,52568 \\
\hline
\end{tabular}

Tabel 6. Data Sampel Pengujian Model Jaringan Syaraf Tiruan Fase S

\begin{tabular}{|l|l|c|c|l|}
\hline Tanggal & Jam & $\begin{array}{l}\text { Aktual } \\
\text { (Watt) }\end{array}$ & $\begin{array}{l}\text { Prediksi } \\
\text { (Watt) }\end{array}$ & Error (\%) \\
\hline 14-Mei-18 & $8: 00$ & 3400,034 & 3366,674 & 0,981167 \\
\hline 14-Mei-18 & $8: 10$ & 2999,303 & 2967,159 & 1,071716 \\
\hline 14-Mei-18 & $8: 20$ & 3391,114 & 3362,284 & 0,850163 \\
\hline 14-Mei-18 & $8: 30$ & 2740,483 & 2697,109 & 1,582714 \\
\hline 14-Mei-18 & $8: 40$ & 2547,733 & 2508,064 & 1,557031 \\
\hline$\cdot$ & $\cdot$ & $\cdot$ & $\cdot$ & $\cdot$ \\
\hline $31-M e i-18$ & $16: 30$ & 1885,736 & 1807,519 & 4,147823 \\
\hline $31-M e i-18$ & $16: 40$ & 1808,375 & 1728,997 & 4,389466 \\
\hline 31-Mei-18 & $16: 50$ & 1344,954 & 1289,82 & 4,099322 \\
\hline 31-Mei-18 & $17: 00$ & 1207,403 & 1147,436 & 4,96661 \\
\hline
\end{tabular}

Tabel 7. Data Sampel Pengujian Model Jaringan Syaraf Tiruan Fase $T$

\begin{tabular}{|l|l|l|r|l|}
\hline Tanggal & Jam & \multicolumn{1}{|c|}{$\begin{array}{l}\text { Aktual } \\
\text { (Watt) }\end{array}$} & $\begin{array}{l}\text { Prediksi } \\
\text { (Watt) }\end{array}$ & Error (\%) \\
\hline 14-Mei-18 & $8: 00$ & 941,96 & 932,899 & 0,96193 \\
\hline 14-Mei-18 & $8: 10$ & 1026,921 & 1026,037 & 0,086083 \\
\hline 14-Mei-18 & $8: 20$ & 1540,715 & 1548,232 & 0,48789 \\
\hline 14-Mei-18 & $8: 30$ & 1629,423 & 1637,828 & 0,515827 \\
\hline$\cdot$ & $\cdot$ & $\cdot$ & $\cdot$ & $\cdot$ \\
\hline $31-M e i-18$ & $16: 30$ & 309,69 & 297,316 & 3,995609 \\
\hline $31-M e i-18$ & $16: 40$ & 309,69 & 298,316 & 3,672705 \\
\hline $31-M e i-18$ & $16: 50$ & 309,69 & 297,322 & 3,993671 \\
\hline $31-M e i-18$ & $17: 00$ & 309,69 & 295,154 & 4,693726 \\
\hline
\end{tabular}

Diketahui bahwa akurasi pengujian memiliki nilai relative aboslute error terkecil adalah $0,883 \%$ dan nilai relative aboslute error terbesar adalah $15,518 \%$. Gambar 7 adalah hasil pengujian model Jaringan Syaraf Tiruan untuk setiap fase pada hari kerja. 

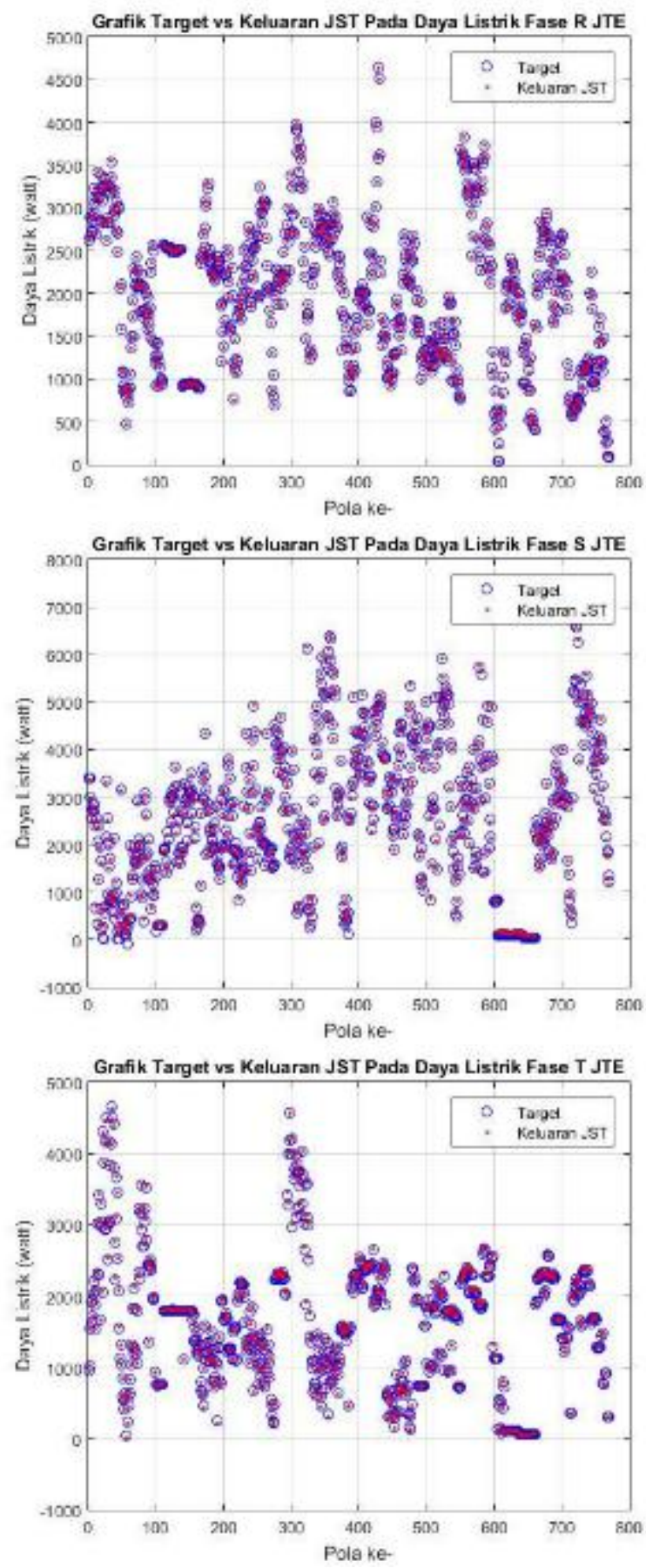

Gambar 7. Sebaran Hasil Pelatihan pada Hari Kerja (Senin-Jum'at)

Gambar 8 adalah hasil pengujian model jaringan syaraf tiruan untuk hari libur.
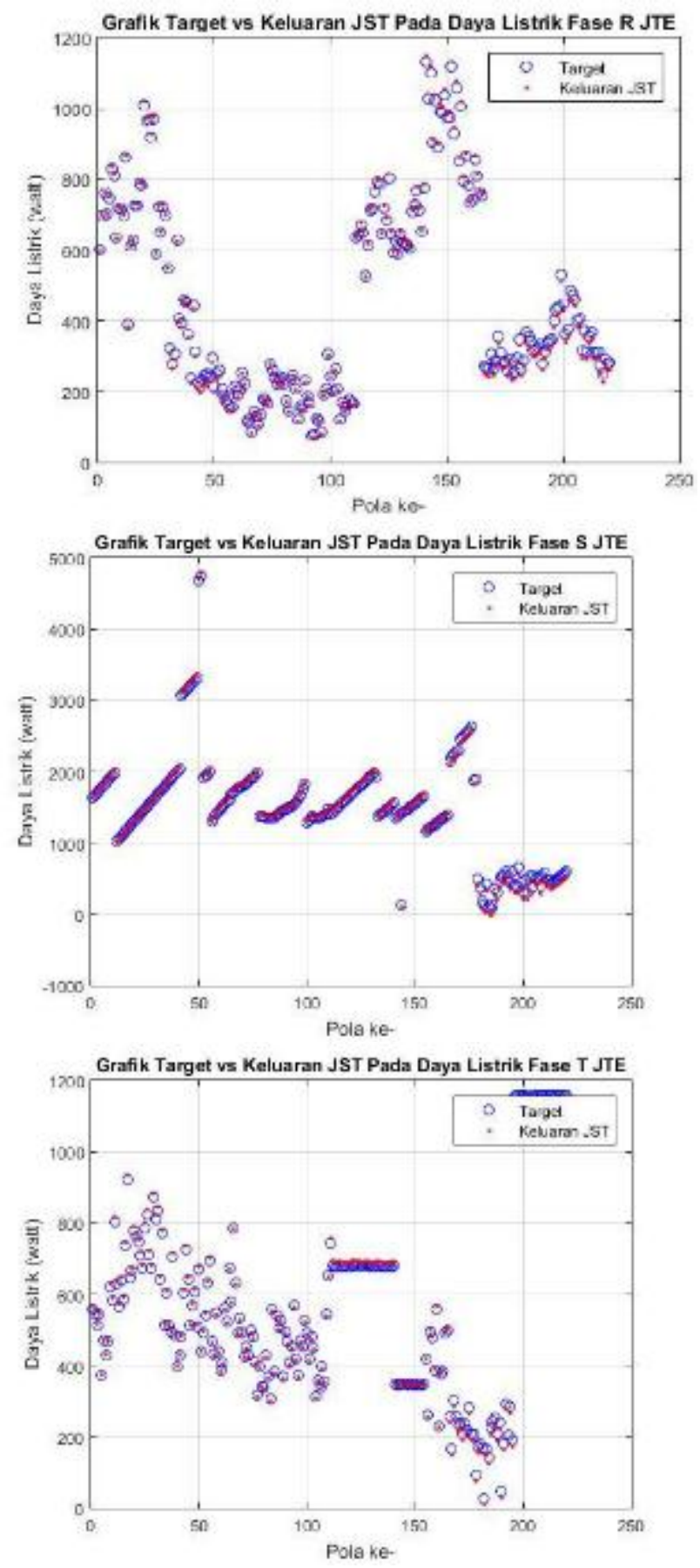

Gambar 8. Sebaran Hasil Pelatihan pada Hari Libur (Sabtu-Minggu dan Liburan)

Model Jaringan Syaraf Tiruan yang dihasilkan telah memiliki akurasi yang cukup baik untuk mempelajari informasi terhadap taburan data daya listrik di masa lampau.

\subsection{Prediksi Kebutuhan Daya Listrik Gedung Teknik Elektro}

Prediksi kebutuhan daya listrik gedung Teknik Elektro dibagi menjadi dua berdasarkan hari kerja (seninjum'at) dan hari libur (sabtu-minggu dan liburan).

Gambar 9 menunjukkan grafik prediksi konsumsi daya listrik pada hari kerja. Terlihat bahwa ada pembebanan yang lebih tinggi pada Fase $\mathrm{S}$. 


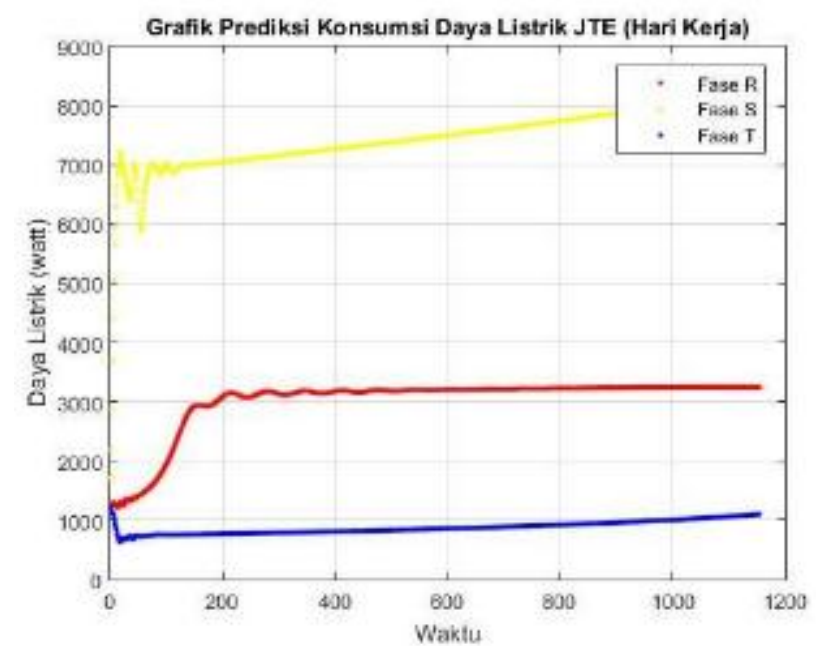

Gambar 9. Prediksi Kebutuhan Daya Listrik Tiap Fase pada hari kerja di Gedung Teknik Elektro Unila Pada Bulan Juni 2018

Gambar 10 menunjukkan grafik prediksi konsumsi daya listrik pada hari libur. Pembebanan juga terlihat tinggi pada Fase S.

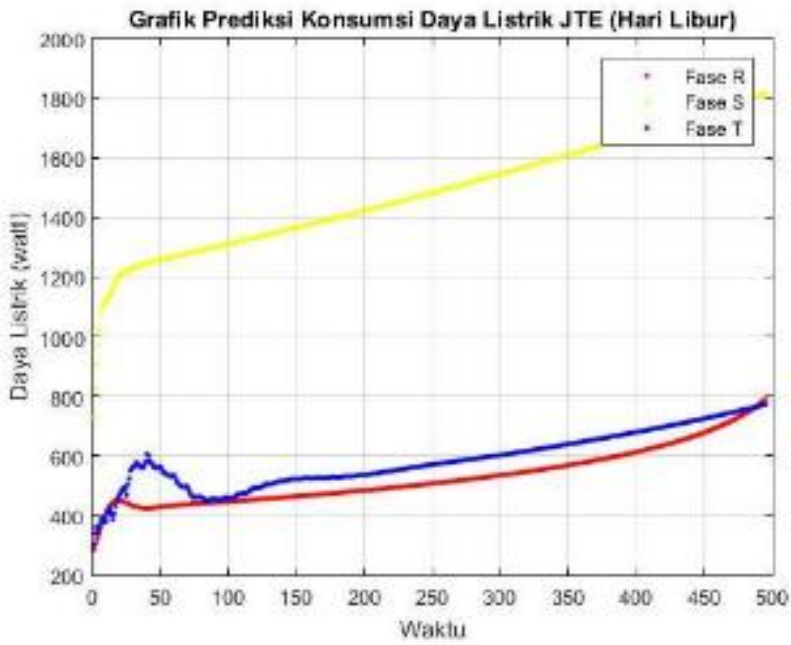

Gambar 10. Prediksi Kebutuhan Daya Listrik Tiap Fase pada hari libur di Gedung Teknik Elektro Unila Pada Bulan Juni 2018

Berdasarkan data pemakaian listrik dari bulan Mei 2018, dapat diprediksi kebutuhan daya listrik pada Gedung Jurusan Teknik Elektro, Fakultas Teknik, Universitas Lampung satu bulan ke depan, yaitu bulan Juni 2018.

Akurasi dari prediksi model Jaringan Syaraf Tiruan untuk kebutuhan listrik di bulan depan adalah 99,11\%. Hal tersebut menunjukkan tingkat akurasi yang tinggi.

Perlu dipahami bahwa daya listrik aktual dari Teknik Elektro Unila ini tergantung pada pengguna beban listrik sehingga hasil yang di prediksi dapat lebih kecil atau lebih besar dari data aktual yang terjadi, tergantung pada aktivitas pengguna beban listrik di Gedung Jurusan Teknik Elektro, Fakultas Teknik, Universitas Lampung tersebut.

\section{KESIMPULAN}

Ketersediaan daya listrik pada sebuah gedung merupakan kebutuhan yang harus disediakan dalam mendukung terlaksananya operasional gedung. Dengan mengetahui penggunaan daya listrik pada sebuah gedung dan perkiraan kebutuhan daya listrik di masa depan, pengelolaan gedung dapat dilaksanakan dan direncanakan dengan lebih baik. Penggunaan Jaringan Syaraf Tiruan dengan Backpropagation membantu dalam melakukan perkiraan kebutuhan listrik. Pada Gedung Jurusan Teknik Elektro Fakultas Teknik Universitas Lampung dipakai listrik tiga fase untuk kebutuhan data listrik, sehingga setiap fase dari listrik harus diukur untuk dapat melakukan prediksi kebutuhan daya listrik.

Dalam melakukan pengukuran listrik tiga fase perlu diingat bahwa fase harus diukur masing-masing karena setiap fase memiliki tingkat pemakaian yang berbeda tergantung dari kondisi di lapangan. Parameter yang harus dijadikan lapisan masukan setidaknya adalah tanggal, hari, hari libur, jam, ruangan, dan pemakaian listrik. Untuk meningkatkan tingkat akurasi dari prediksi kebutuhan listrik tiga fase, perlu dilakukan pemisahan antara hari kerja dan hari libur.

Setelah dilakukan pelatihan dan pengujian dari model jaringan syaraf tiruan, prediksi kebutuhan listrik tiga fase menggunakan Jaringan Syaraf Tiruan memiliki tingkat akurasi yang tinggi, yaitu 99,11\%. Hal ini menunjukkan bahwa Jaringan Syaraf Tiruan dengan Backpropagation dapat digunakan untuk melakukan prediksi kebutuhan daya listrik dengan cukup akurat. Backpropagation menurunkan tingkat error yang cukup rendah sehingga hasil prediksi dapat dijadikan dasar dalam melakukan pengelolaan dan perencanaan perkiraan kebutuhan daya listrik untuk gedung yang menggunakan listrik tiga fase.

\section{SARAN}

Pengembangan lebih lanjut dari sistem prediksi kebutuhan listrik tiga fase perlu dilakukan, sehingga prediksi kebutuhan listrik tiga fase tersedia dalam waktu nyata dan memudahkan pengambilan keputusan terkait dengan pemakaian listrik. Tahapan berikutnya yang dilakukan berdasarkan penelitian ini adalah implementasi model jaringan syaraf tiruan dengan backpropagation ke ERTE System yang dapat memberikan gambaran kebutuhan daya listrik gedung dengan lebih akurat sehingga pengelolaan dan perencanaan kebutuhan daya listrik gedung dapat dilakukan dengan lebih baik.

\section{DAFTAR PUSTAKA}

Asghar, M. H., Negi, A. \& Mohammadzadeh, N., 2015. Principle application and vision in Internet of Things (IoT). Noida, IEEE.

Atika Sari, D., 2006. Prediksi Kebutuhan Beban Jangka Pendek Menggunakan Jaringan Syaraf Tiruan Backpropagation, Semarang: Universitas Diponegoro.

Delano, J., 2018. Estimasi Kebutuhan Daya Listrik Menggunakan Jaringan Syaraf Tiruan Backpropagation Pada Gedung H Fakultas Teknik Universitas Lampung, Bandar Lampung: Universitas Lampung. 
Despa, D. et al., 2019. DASHBOARD PENGAWASAN BESARAN LISTRIK WAKTU NYATA. Barometer, 4(1), pp. 151-154.

Despa, D. et al., 2018. Monitoring dan Manajemen Energi Listrik Gedung Laboratorium Berbasis Internet of Things (IoT). Malang, Fortei.

Despa, D., Nama, G. F., Muhammad, M. A. \& Anwar, $\mathrm{K}$., 2018. The Implementation Internet of Things(IoT) Technology in Real Time Monitoring of Electrical Quantities. London, IOP Publishing.

Jek Siang, J., 2005. Jaringan Syaraf Tiruan dan Pemrogramannya Menggunakan Matlab. Yogyakarta: ANDI.

Kusumadewi, S., 2004. Membangun Jaringan Syaraf Tiruan Menggunakan MATLAB \& EXECL LINK. Yogyakarta: Graha Ilmu.

Pan, J. et al., 2015. An Internet of Things Framework for Smart Energy in Buildings: Designs, Prototype, and Experiments. IEEE Internet of Things Journal, 2(6), pp. 527 - 537.

Ramakrishnan, R. \& Gaur, L., 2016. Smart electricity distribution in residential areas: Internet of Things (IoT) based advanced metering infrastructure and cloud analytics. Pune, 2016 International
Conference on Internet of Things and Applications (IOTA).

Shrouf, F. \& Miragliotta, G., 2015. Energy management based on Internet of Things: practices and framework for adoption in production management. Journal of Cleaner Production, 100(1), pp. 235246.

Tan, Y. S., Ng, Y. T. \& Low, J. S. C., 2017. Internet-ofThings Enabled Real-Time Monitoring of Energy Efficiency on Manufacturing Shop Floors. s.l., Procedia CIRP 61, p. 376-381.

Yanto, M., Sovia, R. \& Mandala, E. P. W., 2018. Jaringan Syaraf Tiruan Perceptron Untuk Penentuan Pola Sistem Irigasi Lahan Pertanian Di Kabupaten Pesisir Selatan Sumatra Barat. Sebatik, pp. 111-115.

\section{UCAPAN TERIMA KASIH}

Terimakasih diucapkan kepada Kemenristekdikti atas Dana Hibah Penelitian Strategis Nasional Institusi berjudul Realtime Web Monitoring dan Estimasi Sistem Kelistrikan dengan Teknologi IoT (Internet Of Things) 